\title{
Censorship in high school libraries in Israel: An exploratory field study
}

\author{
MOSHE YITZHAKI \\ Department of Information and Library Studies, Bar-Ilan \\ University, Ramat-Gan ISRAEL 52900, e-mail: \\ yitzhm@mail.biu.ac.il
}

\section{A B S T R A C T}

The issue of censorship in school libraries has long concerned researchers and practitioners in the field and is well documented in literature. A literature survey reveals dozens of opinion articles as well as research papers reporting empirical field studies, especially in the US, which attempt to determine the extent and objects of censorship and its undertying factors. Although school libraries have existed in israel for several decades, some of them dating back to the 50's, the issue of censorship has not been studied. The objective of the present exploratory study was to empirically assess the current state of censorship in a sample of high school libraries in the country. The sample comprised 25 high schools, from both the 'religious' and 'non-religious' sectors. The main research tool was a two-parts questionnaire, designed to be filled out during researcher's visit to the library. Most librarians reported that some form of control, restriction or censorship was, always or very often, applied to books to be added to the collection, usually by the head librarian. No library had any kind of written document, or even some permanent unwritten statement specifying instructions or policy regarding book acquisition. None of the librarians mentioned any extemal pressure to censor the existing collection or books to be acquired, and it was clear that the only censorship was an intemal one, initiated by the librarians themselves and other members of the school staff. in both sectors there was wide agreement on banning titles which included violence, hard pormography, racism and drugs, but there were considerable differences regarding 'soft' pomography, Holocaust denial, sexual pemissiveness and books degrading the Jewish religion or its values, principles or commands. A comparison of four lists of specific titles against the catalogs showed that the 'non-religious' libraries owned three times the percentage from the first list (explicit violence and sex), but only half the percentage from the fourth list ('Judaism'), compared to the 'religious' one. Interestingly, the religious group had lower percentages of both the 'rightist' and 'leftist' lists, due to its smaller collections, but relatively more from the 'rightist' list than the 'leftist' one.

\section{Background}

The issue of censorship in school libraries has long concerned researchers and practitioners in the field and is well documented in literature. A literature survey reveals dozens of opinion articles as well as research papers reporting empirical field studies, especially in the US, which attempt to determine the extent and objects of censorship and its underlying factors.

Education for All: Culture, Reading and Information, IASL, 1998 
Discussing research on censorship attempts in school libraries, Hansen (1987) and Martorelli (1982) pointed out the increase in school censorship and the often unclear use of the term. Hopkins reviewed (1989) the literature to identify factors influencing the results of censorship attempts regarding school library materials and developed (1993) a conceptual model encompassing the various factors involved, especially in secondary school settings. Woods (1989) published an annotated bibliography covering more than a decade and Foerstel, in his 'reference guide' book Banned in the USA (1994), focused on book-banning in public schools and libraries, and pointed out that the major grounds for censorship were sex, profanity and religion, which were often intertwined to cover a broad range of "unacceptable" attitudes or ideas. Symons and Harmon's Protecting the Right to Read (1995) discusses the issue of intellectual freedom in libraries and offers guidelines for ensuring the right to read.

It is worth noting that challenges to school library materials came not only from 'external' sources (parents, citizens' organizations etc.-Martorelli 1982) but also from the school community itself, like principals (Hopkins 1995), librarians (Serebnik 1982), media specialists (Woods \& Salvatore 1981) and other school personnel at all levels (Burress 1967). In a recent article, Schrader (1996) explains why challenges to school library materials are unavoidable and points out that the method of 'censorproofing' by title, author etc. is a wrong substitute for professional responsibility.

\section{Purpose of the study}

Although school libraries have existed in Israel for several decades, some of them dating back to the 50's, the issue of censorship has not been studied. The objective of the present study was to empirically assess the current state of censorship in a sample of high school libraries in the country. Since, this issue has never been examined here, our study was designed as an exploratory one, with the intention of later carrying out a large scale full-blown study, based on the lessons learned.

\section{Methodology}

The sample comprised 25 high schools located in various regions of the country, from Haifa in the north to Beer-Sheba in the south, each with a library of at least several thousand books. The Jewish educational system in Israel is traditionally divided into three state-supported sectors: (1) the 'non-religious' sector ('Mamlahti') which encompasses about $70 \%$ of the schools, (2) the 'religious' sector ('Mamlahti Dati') affiliated with the modern-orthodox movement, and (3) the 'Haredi' sector, affiliated with the ultra-orthodox movement and consisting of three main factions: Lithuanian, Hassidic and Sephardic. Since a main hypothesis was that school affiliation is a major factor affecting the extent of censorship, the sample was designed to include 15 schools belonging to the 'non-religious' sector and 10 schools belonging to the 'religious' one.

In choosing the sample, intention was given to include schools from various socioeconomic sectors, in urban and non-urban areas. Thus, the 'non-religious' subsample included four schools located in the Greater Tel-Aviv area, four others-in large cities (like Netania, Petah-Tikva etc.), three-in smaller towns (like Or Yehuda, Kiriat-Ono etc.) and four 
located in rural areas. The ten 'religious' schools were similarly divided, but included no schools from the rural sector.

As far as school type was concerned, the sample was divided almost evenly between regular high schools (12) and 'multi-track' ('Makif') ones (13) which in Israel denotes a high school offering several alternative tracks. No vocational school was included.

The main research tool was a lengthy two-parts questionnaire, designed to be filled out during researcher's visit to the library. The first part, which required a personal interview with the librarian, included 13 closed questions regarding the school, its library size and librarian's education. Three additional questions referred in general to the extent and source of censorship applied. The working definition given to 'censorship' in this study was: "any type of supervision, control or restriction applied when adding new book titles to the library collection."

The last question of this part included a list of 22 controversial topics (violence, pornography, racism, drugs, etc.) from which the librarian was asked to indicate those which she or he "would prefer in principle to exclude from the collection." Following Serebnik's study (1982), the second part of the questionnaire consisted of four separate lists of 25 to 30 book titles, to be checked against the library catalog, in order to verify whether the library carries them. The four lists included particular original and translated fiction books and original non-fiction ones, in Hebrew, with the following features, each of which was typical to one of the lists: (1) violence, explicit sex relations, etc. (2) right-wing orientation, (3) left-wing orientation, (4) Judaism, Jewish classics, repentance, etc. Most titles were considered controversial to various degrees and were obtained using the Delphi method among teachers and librarians studying in the Bar-llan Department of Information and Library Studies.

\section{Findings and discussion}

\section{Demographic features:}

Sixty percent of the 25 schools included in the exploratory sample ( 15 out of 25 , were six-year high schools ( 7 th to 12th grades), and the rest were mostly upper three-year ones $\left(10^{\text {th }}-12^{\text {th }}\right.$ grades), with only one junior high school (grades 7 th to 9 th). As can be seen in Table 1, the internal division among the two different sectors was similar, except for the fact that the 'religious' subsample had a relatively higher proportion of six-year high schools $(70 \%$ vs. $53 \%$ in the 'non-religious' one). The almost total exclusion of junior high schools was deliberate, since the content of the titles in the four lists seemed more suited to higher grades. 
Table 1: Level of High Schools Sampled

\begin{tabular}{lllll}
\hline & Non-Religious & & Religious & \\
& No. & $\%$ & No. & $\%$ \\
Junior High & 1 & 6.7 & 0 & 0 \\
Upper Three-year & 6 & 40.0 & 3 & 30.0 \\
Six-year & 8 & 53.3 & 7 & 70.0 \\
Total & 15 & $100 \%$ & 10 & $100 \%$ \\
\hline
\end{tabular}

The vast majority of the schools, 20 out of 25 , had existed more than 20 years, with the remaining five (20\%) aging between 11 and 20 years. In the religious sector only one school aged between 16-20 years, while all nine others (90\%) were older.

Understandably, since most schools experience some delay in establishing a library, the libraries in the schools sampled dated slightly younger than the schools themselves: about $60 \%$ were established more than 20 years ago, about $25 \%$ were between 11 and 20 years old, and only less than $8 \%$ (two libraries) were younger, aging between 6 and 10 years. Interestingly, although the religious schools in the sample were slightly older than the non-religious ones (90\% of the former aging more than 20 years vs. $73 \%$ of the latter) the libraries in the religious sector were slightly younger, a likely indication of less attention given to this important aspect of school life there.

\begin{tabular}{|c|c|c|c|c|}
\hline & \multirow{2}{*}{\multicolumn{2}{|c|}{ Non-Religious }} & \multirow{2}{*}{\multicolumn{2}{|c|}{ Religious }} \\
\hline & & & & \\
\hline & No. & $\%$ & No. & $\%$ \\
\hline $251-500$ & 1 & 6.7 & 3 & 30.0 \\
\hline $501-750$ & 1 & 6.7 & 6 & 60.0 \\
\hline $751-1000$ & 2 & 13.3 & 1 & 10 \\
\hline $1001-1500$ & 5 & 33.3 & & \\
\hline $1501-2000$ & 2 & 13.3 & & \\
\hline More than 2000 & 4 & 26.7 & & \\
\hline Total & 15 & $100 \%$ & 10 & $100 \%$ \\
\hline
\end{tabular}

Table 2 indicates that the two sectors differed significantly regarding size of student population. While most schools in the non-religious sector (about $75 \%$ ) had relatively large student populations, of over 1000 , with $25 \%$ having even more than 2000 each, the vast majority $(90 \%)$ of the religious schools in the sample had only 251 to 750 students, with only one school in the 751-1000 category.

School size, presumably, had implications on the size of library collection, as shown in Table 3. The libraries in the non-religious schools were fairly large, whether measured in titles or volumes. The upper forty percent reported a collection size of over 10000 titles (half of these had over 20000 each!), one-third had between 5000 and 10000, and only one-quarter had smaller collections of 2500-5000 titles. In the religious sector, in contrast, collections were much smaller: 70\% of the libraries owned between 2501 and 7500 titles only, $20 \%$ had less than 2500 , and only one library had 7501 to 10000 . 
Table 3: $\quad$ Size of Library Collections in High Schools Sampled (in \%)

\begin{tabular}{|c|c|c|c|c|}
\hline & \multicolumn{2}{|c|}{ Non-Religious } & \multicolumn{2}{|c|}{ Religious } \\
\hline & Titles & Volumes & Titles & Volumes \\
\hline $501-1000$ & & & 10.0 & \\
\hline $1001-2500$ & & & 10.0 & 20.0 \\
\hline 2501-5000 & 26.7 & 13.3 & 30.0 & 30.0 \\
\hline $5001-7500$ & 13.3 & & 40.0 & 10.0 \\
\hline 7501-10000 & 20.0 & 13.3 & 10.0 & 20.0 \\
\hline 10001-20000 & 20.0 & 40.0 & & 20.0 \\
\hline More than 20000 & 20.0 & 33.3 & & \\
\hline Total & $100 \%$ & $100 \%$ & $100 \%$ & $100 \%$ \\
\hline
\end{tabular}

Volume-wise, the picture was similar: an over- 10000 collection was owned by about $75 \%$ of the libraries in the non-religious sector, including 33\% which reported more than 20000 volumes, while $60 \%$ of the religious schools libraries reported collections of less than 7500 volumes and only $40 \%$ reported larger collections, up to 20000.

In both sectors, the non-fiction was generally much larger than the fiction collection: while only $7 \%$ among the non-religious sector reported a non-fiction collection smaller than 2500 volumes, $47 \%$ of these libraries reported a fiction-collection of such small size. Forty percent reported a nonfiction collection greater than 10000 volumes, but only $13 \%$ had a fiction collection of that size. A similar difference was found in the religious sector, but on a smaller scale, due to its smaller library size: $50 \%$ of the libraries had a non-fiction collection of 2500 to 10000 volumes, but in $80 \%$ (!) of these the fiction collection comprised 2500 volumes or less. 
Table 4: Size of Fiction and Non-fiction Collections in High

Schools Sampled (in \%)

\begin{tabular}{|c|c|c|c|c|}
\hline & Non-Religious & & Religious & \\
\hline $\begin{array}{l}\text { Volumes } \\
\text { up to } 500\end{array}$ & Non-fiction & Fiction & Non-fiction & $\begin{array}{l}\text { Fiction } \\
20.0\end{array}$ \\
\hline $501-1000$ & & 20.0 & 30.0 & 40.0 \\
\hline $1001-2500$ & 6.7 & 26.7 & 20.0 & 20.0 \\
\hline $2501-5000$ & 26.7 & & 20.0 & 10.0 \\
\hline $5001-7500$ & 6.7 & 20.0 & 10.0 & 10.0 \\
\hline $7501-10000$ & 20.0 & 20.0 & 20.0 & \\
\hline $10001-20000$ & 26.7 & 6.7 & & \\
\hline More than 20000 & 13.3 & 6.7 & & \\
\hline Total & $100 \%$ & $100 \%$ & $100 \%$ & $100 \%$ \\
\hline
\end{tabular}

Differences in library size between the two sectors showed also in their 'annual growth' measured by the 'number of volumes added in the previous year'. In the non-religious sector almost half of the libraries had added 751 to 2500 volumes, and another $40 \%$ added between 251 and 750 , totaling $86 \%$ which had acquired over 250 volumes in that year. In the religious sector half of the libraries had added less than 100 volumes in that year and another $40 \%$ had added between 100 and 500 .

The two sectors also differed in the education of the head librarian: almost $75 \%$ of head librarians in the non-religious sector were academically educated vs. only $50 \%$ in the religious sector. There was also a slight difference in academic librarianship education, which was more prevalent in the former sector $(40 \%)$ than in the latter $(30 \%)$.

\section{Application of Censorship in practice}

The first part of the questionnaire included, besides the 'demographic' questions, several direct questions regarding the type and extent of 'censorship' actually employed in the library. The first question was phrased as follows: "In your library, is there any type of supervision, control or restriction over the content of books added to the collection?"

Table 5 shows that $40 \%$ of the libraries, in both sectors, chose the first response: "Always, as a regular and constant routine, regarding every book added to the collection." Another twenty percent of non-religious school libraries did so "frequently, but not always," while in the religious sector the proportion of this response was double $(40 \%)$. Those doing it "seldom" amounted to one-third in the former sector, but to only $20 \%$ in the latter one. In the whole sample, only one library, affiliated with the non-religious sector, chose the option of "Never." 


\section{Table 5: Frequency of Exerting 'Censorship' When Acquiring New Books}

\begin{tabular}{lllll}
\hline \multicolumn{1}{l}{ Non-Religious } & Religious & \\
Frequency of 'censorship' & No. & $\%$ & No. & $\%$ \\
Always & 6 & 40.0 & 4 & 40.0 \\
Often & 3 & 20.0 & 4 & 40.0 \\
Seldom & 5 & 33.3 & 2 & 20.0 \\
Never & 1 & 6.7 & & $100 \%$ \\
Total & 15 & $100 \%$ & 10 & \\
\hline
\end{tabular}

Thus, it can be said that most libraries in both sectors (60\% and $80 \%)$ applied some kind of 'censorship' always or at least frequently. Table 5 as well as personal impressions of the interviewers, indicate that this practice (i.e. applying some kind of 'censorship') is considered common and legitimate, even positive, certainly nothing to be ashamed of, among the librarians interviewed. One should bear in mind that they could easily have denied any kind of 'censorship' in their library or at least reduced its frequency, had they considered it an 'unacceptable' practice.

\section{Table 6: Person Responsible for Applying 'Censorship' When Acquiring New Books}

\begin{tabular}{lllll}
\hline \multicolumn{2}{l}{ Non-Religious } & \multicolumn{2}{l}{ Religious } \\
Responsible Person & No. & $\%$ & No. & $\%$ \\
Head Librarian & 11 & 80.0 & 4 & 40.0 \\
Other Librarian & 1 & 6.7 & & \\
School Principal & 1 & 6.7 & 2 & 20.0 \\
Head Librarian + & & & 1 & 10.0 \\
Teacher(s) & 1 & 6.7 & 1 & 10.0 \\
$\begin{array}{l}\text { Head Librarian + } \\
\text { Teacher(s) + School }\end{array}$ & & & & \\
$\begin{array}{l}\text { Principal } \\
\text { Head Librarian + School }\end{array}$ & & & 2 & 20.0 \\
$\begin{array}{l}\text { Principal } \\
\text { No Restriction }\end{array}$ & 1 & 6.7 & & $100 \%$ \\
Total & 15 & $100 \%$ & 10 & \\
\hline
\end{tabular}

Table 6 summarizes the answers to the next question: "Who is responsible for this supervision, control, or restriction, and carries it out routinely?" In all schools the 'censorship' clearly did not derive from any external source, outside the school, but was rather an 'internal censorship', coming from within the school itself. Again, the two sectors differed significantly: while in the non-religious one almost $80 \%$ of the libraries reported that the 'censorial supervision' was done entirely by the librarians, this was the case in only 
$40 \%$ of the libraries in the religious sector, with the rest reporting that this task was carried out either by the school principal alone $(20 \%)$, or with the librarian $(20 \%)$ and/or teachers (20\%). This may attest to less independence and lower status of the librarians in the religious sector schools. On the other hand, it may indicate, at least in some of these schools, a cooperative effort in the process of collection building, to ensure better suitability to the schools' curriculum and educational goals. None of the librarians interviewed mentioned any external pressure to censor the existing collection or books to be acquired by the library, and it was clearly indicated that the only censorship was an internal one, initiated by the librarians themselves and/or others of the school staff, although many of them were probably unaware that they had been doing so.

Table 7 summarizes the answers to the question: "Does your library have any rules or guidelines for the practical application of this 'censorship'?"

\begin{tabular}{|c|c|c|c|c|c|}
\hline \multirow[t]{3}{*}{ Table 7: } & \multicolumn{5}{|c|}{$\begin{array}{l}\text { Existence of Rules or Guidelines for the Practical } \\
\text { Application of 'Censorship' }\end{array}$} \\
\hline & \multirow[b]{3}{*}{ Routine } & \multicolumn{2}{|c|}{ Non-Religious } & \multicolumn{2}{|c|}{ Religious } \\
\hline & & No. & $\%$ & No. & $\%$ \\
\hline $\begin{array}{l}\text { Written } \\
\text { Guidelines }\end{array}$ & & & & & \\
\hline $\begin{array}{l}\text { Unwritten } \\
\text { Guidelines }\end{array}$ & Routine & 1 & 6.7 & 4 & 40.0 \\
\hline $\begin{array}{l}\text { No Routine } \\
\text { all }\end{array}$ & Guidelines at & 14 & 93.3 & 6 & 60.0 \\
\hline Total & & 15 & $100 \%$ & 10 & $100 \%$ \\
\hline
\end{tabular}

Most libraries, in both sectors, had no routine guidelines, or even some unwritten instructions or policy regarding the practical application of the 'internal censorship', and none had any kind of written document. This finding seems quite inconsistent with the above findings (Table 5) that between $60 \%$ and $80 \%$ of the libraries sampled actually apply, always or frequently, some extent of 'censorship' in the continuous process of collection building. The likely explanation is that most libraries solve the problems intuitively, judging each case in itself, and that hitherto there were no controversial cases which could have drawn the public and media attention and obliged the libraries to form some code of relevant rules and guidelines. Another significant difference between the sectors is noteworthy: while $40 \%$ of the religious libraries reported having 'unwritten rules or guidelines', this proportion in the non-religious sector was only $7 \%$, a clear indication of a much greater awareness of the issue of 'undesirable books' in the former sector, and greater degree of openness and permissiveness in the latter one.

The last question in the first part of the questionnaire specified 22 topical categories of books and the librarian was asked to check those which "his library would prefer, in principle, to exclude from its collection, i.e. 'undesirable' items." Due to its exceptional size and the quantity of tables and analyses based on the answers to this long and lengthy question, it had to be left for a separate publication.

However, several interesting findings should be briefly mentioned: 
1. 'Hard' pornography and 'hard' violence topped the 'undesirable' list in both sectors, being rejected by $100 \%$ of the libraries in the religious sector, as opposed to $93 \%$ and $80 \%$ (respectively) in the other sector.

2. Racism, and advocating of drug use were next on the list, being rejected by 75 to 80 percent in both sectors, while a positive approach to mystical closed and bizarre sects ('Devil Worshippers' etc.) was rejected by about two-thirds.

3. Expectedly, the prominent difference between the two sectors emerged again regarding books whose content "encouraged sexual permissiveness" or degraded the Jewish religion, beliefs, commands, principles or values." Such books would be rejected by all libraries in the religious sector, with no exception, but only by $50 \%$ of the libraries in the non-religious one.

\section{Collection balance}

The second part of the questionnaire included four lists of specific book titles (25 to 30 in each list) to be checked against the library catalog, in order to verify the reliability of the librarians' answers to the first part of the questionnaire, using the 'triangulation' technique, as well as to look for possible political or ideological 'biases' in the collections. The four lists included Hebrew titles dealing with: (1) violence, explicit sex relations, etc. (2) right-wing orientation, (3) left-wing orientation, (4) Judaism, Jewish classics, repentance, etc. Proportions of titles held, for each of the four lists, were calculated for each library, as well as measures of central tendency and variability for each of the sectors, as shown in Table 8.

\begin{tabular}{|c|c|c|c|c|}
\hline \multirow[t]{2}{*}{ Table 8: } & \multicolumn{2}{|l|}{ of Titl } & \multirow[b]{2}{*}{ Religious } & \multirow[b]{3}{*}{ Median } \\
\hline & Non-Re & & & \\
\hline Topic of Title List & $\begin{array}{l}\text { Mean } \\
\text { (SD) }\end{array}$ & Median & $\begin{array}{l}\text { Mean } \\
\text { (SD) }\end{array}$ & \\
\hline $\begin{array}{l}\text { Violence, soft } \\
\text { pornography, etc. }\end{array}$ & $\begin{array}{l}58.8 \% \\
(19.5)\end{array}$ & $57 \%$ & $\begin{array}{l}18.3 \% \\
(15.0)\end{array}$ & $15 \%$ \\
\hline Right-wing orientation & $\begin{array}{l}28.8 \% \\
(20.1)\end{array}$ & $24 \%$ & $\begin{array}{l}18.4 \% \\
(7.3)\end{array}$ & $16 \%$ \\
\hline Left-wing orientation & $\begin{array}{l}45.9 \% \\
(23.8)\end{array}$ & $36 \%$ & $\begin{array}{l}10.4 \% \\
(8.7)\end{array}$ & $12 \%$ \\
\hline $\begin{array}{l}\text { Judaism, Jewish classics, } \\
\text { repentance, etc. }\end{array}$ & $\begin{array}{l}31.7 \% \\
(12.6)\end{array}$ & $32 \%$ & $\begin{array}{l}59.5 \% \\
(14.2)\end{array}$ & $62 \%$ \\
\hline $\mathrm{N}$ & 15 & 15 & 10 & 10 \\
\hline
\end{tabular}

Analysis of the proportions owned from each of the four lists revealed considerable differences between the two sectors: the 'non-religious' group had three to four times the percentage from the first list (explicit violence and sex), but only half the percentage from the fourth list ('Judaism'), compared to the 'religious' one. Interestingly, the religious group had lower percentages from both the 'rightist' and 'leftist' lists, compared to the 'non-religious' group, a fact which is probably explained by their relatively smaller collections, as shown above (Table 3 and 4 ). Nevertheless, the religious group had relatively more titles from the 'right' list compared to the 'left' one (18\%-16\% vs. 
$10 \%-12 \%$ ), while the non-religious group had significantly more titles from the 'left' list: $46 \%$ vs. $29 \%$ (or $36 \%$ vs. $24 \%$ if medians are compared).

The difference between the two sectors concerning the proportion of 'right' and 'left' titles owned by each is also illustrated by another measure, which is based on the following ratio:

\section{Average group percentage of 'left' titles held by libraries of that sector}

Average group percentage of 'right' titles held by libraries of that sector

Table 9 presents the ratios for each sector, calculated on the basis of group means and medians, again indicating the significant difference and 'collection bias' of each sector.

\section{Table 9: Ratio of 'Leftist'. / 'Rightist' Group Percentages in Both Sectors}

\begin{tabular}{lll} 
Ratio 'Leftist'/ 'Rightist' & Non-religious sector & Religious sector \\
Between Group Means & 1.97 & 0.545 \\
Between Group Medians & 1.80 & 0.62 \\
\hline
\end{tabular}

This finding is explained by the different political and ideological orientation of library and school staff employed in each sector. It has long been established by Israeli sociologists and political scientists that the religious sector in Israel has a much more 'right-wing' orientated than the non-religious one.

Two points, however, should not be overlooked: (1) the great variability within each of the two groups, as indicated by the relatively high measures of standard deviations, denoting significant individual differences between libraries in the same sector. (2) Neither sector totally bans titles identified with the opposite sector. On the average the non-religious sector owned $29 \%$ (or 24\%) of the titles included in the 'rightist' list, and the religious sector owned $10 \%$ (or $12 \%$ ) of the 'leftist' titles, probably due to its smaller collections.

The large difference regarding the 'Judaism' list is, of course, explained by the very nature, orientation and ideological foundations of both sectors, and the much greater emphasis placed by the religious sector on Judaism, Jewish classics etc.

\section{Conclusions}

1. Most libraries in the sample actually apply some form of 'censorship' to books added to their collection, but this 'censorship' is internal rather than originating in sources outside the school.

2. Most libraries had no kind of written or unwritten document which specifying rules or guidelines for applying these abovementioned 'censorship'.

3. School libraries in the religious sector differ from those in the non-religious one in their smaller collections, much fewer titles containing explicit sex, many more titles on Jewish topics and much lower ratio between 'left' and 'right' oriented titles.

4. However, caution is warranted since these conclusions are based on a relatively small sample of 25 libraries and a limited list of selected titles. Further research is needed, including a much larger sample of high school libraries, and different lists of titles representing the four topic areas mentioned above. 


\section{References}

Boardman, Edna a.o. (1993). Censorship and intellectual freedom in the schools. Book Report, 11(5): 14-27.

Burress, Lee A., Jr. (1967). The Role of English Teachers and Librarians in Book Selection. (ED 250 681).

Foerstel, Herbert N. (1994). Banned in the USA: Reference Guide to Book Censorship in Schools and Public Libraries. Westport, CT, Greenwood Press.

Hansen, Eileen. (1987). Censorship in schools: studies and surveys. School Library Journal, 34(1): 123-125.

Hopkins, Dianne McAfee. (1989). Toward a conceptual model of factors influencing the outcome of challenges to library materials in school settings. Library and Information Science Research, 11(3): 247-271

Hopkins, Dianne McAfee. (1993). A conceptual model of factors influencing the outcome of challenges to library materials in secondary settings. Library Quarterly, 63(1): 40-72.

Hopkins, Dianne McAfee. (1995). Challenges to library materials from principals in united states secondary schools - A "Victory" of Sorts. School Library Worldwide, 1(2): 8-29.

Martorelli, Debra. (1982). When the Censor Calls ... How Will You Answer. Instructor and Teacher, $91: 92$.

Oboler, Eli M. (1980). The controversy surrounding values education. School Library Journal, 27 (2): 115-117.

Schrader, Alvin M. (1996). Censorproofing school library collections: the fallacy and futility, School Libraries Worldwide, 2 (1): 71-94.

Serebnik, Judith. (1982). Self-censorship by librarians: an analysis of checklist-based research, Drexel Library Quarterly 18 (1): 35-56.

Symons, Ann K. \& Harmon, Charles. (1995). Protecting the Right to Read: A How-To-Do-It Manual for School and Public Librarians. (ED 391 529).

Woods, L.B. (1989). Bibliography on Censorship and Intellectual Freedom, 1976-88. (ED 314 054).

Woods, L.B. \& Salvatore, L. (1981). Self-censorship in collection development by high school library media specialists. School Media Quarterly, 9(2):102-108. 